\title{
Screening of Groundnut Genotypes for Early and Late Leaf Spot Disease
}

\author{
Ishu Kumar Khute*, S.S. Rao, Preeti Painkra, Naveen Markam, \\ Krishna Tandekar and Nandan Mehta
}

\begin{abstract}
Department of Genetics and Plant Breeding, College of Agriculture, Indira Gandhi Krishi Vishwavidyalaya, Raipur - 492 012, Chhattisgarh, India
\end{abstract}

*Corresponding author

\begin{abstract}
A B S T R A C T
Keywords

Groundnut,

Screening, Early

leaf spot, Late leaf spot

Article Info

Accepted:

24 January 2018

Available Online:

10 February 2018

The present investigation was conducted to study screening of groundnut genotypes for early and late leaf spot disease 25 genotypes were sown at Research Farm, Department of Genetics and Plant Breeding, Indira Gandhi Krishi Vishwavidyalaya, Raipur, (C.G.). Two genotypes TG 11 and JL 775 showed highly resistance against early leaf spot nine genotypes showed resistance reaction and 12 genotypes showed moderate resistance and for late leaf spot two genotypes TG 11 and Girnar 3 showed highly resistance, one genotype showed resistance reaction and 10 genotypes showed moderate resistance that can be used for further resistance breeding programme.

\section{Introduction}

Groundnut is an important food crop of the world. Groundnut (Arachis hypogaea L.), chromosome no. $2 \mathrm{n}=40$ is an important monoecious annual legume in the world mainly grown for oil seed, food and animal feed (Pande et al., 2003; Upadhyaya et al., 2006). All parts of the peanut plant can be easily utilized. Besides income for farmers, groundnut provides an inexpensive source of high quality dietary protein and edible oil. The vast food preparations incorporating groundnut to improve the protein level has helped in no small way in reducing malnutrition in the developing countries. The

special taste and flavour of foods containing groundnut is very important in the acceptance of these food preparations. It is estimated that the shell represents about $25 \%$ of the dry weight of unshelled peanut, and the kernel comprises $75 \%$. Groundnut seeds contain high quality edible oil (50\%), easily digestible protein $(25 \%)$, carbohydrates $(20 \%)$, vitamin E, niacin, folacin, calcium, phosphorus, magnesium, zinc, iron, riboflavin, thiamine and potassium (FAO, 2004). Worthington and Hammons (1971) reported that the seed has several uses as whole seed or processed to make peanut butter, oil, soups, stews and other products. Nearly two thirds of all groundnuts are crushed for oil (Bunting et al., 1985).
\end{abstract}


Oil is the most important product of groundnut. Oil from unshelled nuts is preferred due to less risk of the oil turning rancid and low incidence of Aspergillus flavus infestation. Groundnut oil is used as fuel in diesel engines and lighting and also in the manufacture of peanut butter, margarine, furniture creams, salad oils, soaps and cooking oil and for cooking sardines before packing them in olive oil. The groundnut cake obtained after oil extraction and groundnut haulms are useful animal feeds. The cake is also used in infant food formulations.

Groundnut protein is increasingly becoming important as food and feed sources, especially in developing countries where protein from animal sources are not within the means of the majority of the populace. The peanut is wellestablished snack food as fresh, cooked and roasted. The leaves and stems (haulms) can also be ploughed into soil or prepared into silage for feeding animals. The shells or pods can be used as feed for livestock, burned for fuel, made into particle board and many other uses (Williams et al., 1989; Levetin and McMahon, 1999; Anonymous, 2004).

Early leaf spot caused by Cercospora arachidicola and late leaf spot caused by Cercosporidium personatum. Early leaf spots are brown to reddish brown in color and always have a yellow halo. Most of the early leaf spot spores are formed on the upper leaf surface giving it a slightly raised surface, while lower leaf surface is usually smooth. Late leaf spots are characterized by dark brown to black spots and usually do not have yellow halo. Most of the late leaf spot spores are formed on the lower surface giving it a rough and tufted appearance, whereas upper leaf surface is generally smooth. Leaf spot can cause yield losses up to $50 \%$ worldwide (Tshilenge et al., 2012) in India, losses in yield due to leaf spot have been estimated to be in the range of $15-59 \%$.

\section{Materials and Methods}

For screening of leaf spot disease the experiment was conducted at Research Farm, Department of Genetics and Plant Breeding, Indira Gandhi Krishi Vishwavidyalaya, Raipur (C.G.). For this purpose 25 genotypes GG 7, TG 11, Kadiri 3, GJG 17, GJG 22, GG 20, JL 501, Somnath, GG 5, GJG 9, GG 11, GJG 37A, GAUG 10, BAU 13, GG 2, Kausal 16, GG 8, ICGV 91114, JL 775, Kadiri 6, Girnar 3, CS 186, IGS 2015-2, Jyoti and IGS 2015-1 were sown in RCBD with three replications during Kharif 2016. Each entry was raised in two rows of $3 \mathrm{~m}$ length with a row to row spacing $45 \mathrm{~cm}$ apart with $15-20 \mathrm{~cm}$ interplant distances. The sowing date of crop was August 25, 2016.

Data collection on leaf spot disease was based on a subjective visual score as follows: $1=$ highly resistant, $1-3=$ resistant, $4-5=$ moderate resistance, $6-7=$ susceptible and 8 - 9 = highly susceptible (ICRISAT, 1995). Yield data were taken after harvesting and drying the haulms and pods to a constant mass. Disease score indicates $0 \%=$ highly resistant, $1-20 \%=$ resistant, $21-50 \%=$ moderate resistance, $51-70 \%=$ susceptible and $71-100 \%=$ highly susceptible. Data on leaf spots was collected at 75 and 85 days from planting.

\section{Results and Discussion}

\section{Reactions of groundnut genotypes for early leaf spot}

Among the 25 genotypes (Table 1) five genotypes namely- Somnath, GG 8, ICGV 91114, JL 775 and Girnar 3 showed 1 disease score which indicates highly resistant reactions against the early leaf spot disease and nine genotypes GG 7, TG 11, GJG 22, GG 20, GG 5, GG 11, Kadiri 6, IGS 2015-2 and IGS 2015-1 showed 3 disease score that 
indicates resistance disease reactions and 11 genotype Kadiri 3, GJG 17, JL 501, GJG 9, GJG 37 A, GAUG 10, BAU 13, GG 2, Kausal 16, CS 186 and Jyoti showed moderate resistance and none of the genotypes showed susceptible and highly susceptible at 35 day after showing.

Second observation for screening was taken at 45 days after sowing in which two genotype TG-11 and JL-775 showed 1 disease score that indicates highly resistance reactions against the disease, nine genotypes GG 7, GJG 22, GG 20, Somnath, GG 11, GG 8,ICGV 91114, Girnar 3 and IGS 2015-2 showed 3 disease score means resistance reactions, 12 genotypes Kadiri 3, GJG 17, JL 501, GJG 9, GJG 37A, GAUG 10, BAU 13, Kausal 16, Kadiri 6, CS 186, Jyoti and IGS 2015-1 showed 5 disease score indicating moderate resistance, two genotypes GG 5 and GG 2 showed susceptible reaction and no any genotypes found as highly susceptible. Similar results also reported by Mane (2004) and Hossain et al., (2007).

Table.1 Screening of groundnut genotypes for early and late leaf spot

\begin{tabular}{|c|c|c|c|c|c|}
\hline \multirow[t]{2}{*}{ S.N. } & \multirow[t]{2}{*}{ Genotypes } & \multicolumn{2}{|c|}{$\begin{array}{l}\text { Disease score for early leaf spot } \\
(\%)\end{array}$} & \multicolumn{2}{|c|}{$\begin{array}{c}\text { Disease score for late leaf spot } \\
(\%)\end{array}$} \\
\hline & & $\begin{array}{l}35 \text { days after } \\
\text { sowing }\end{array}$ & $\begin{array}{l}45 \text { days after } \\
\text { sowing }\end{array}$ & $\begin{array}{l}75 \text { days after } \\
\text { sowing }\end{array}$ & $\begin{array}{l}85 \text { days after } \\
\text { sowing }\end{array}$ \\
\hline 1 & GG 7 & 3 & 3 & 1 & 3 \\
\hline 2 & TG 11 & 3 & 1 & 3 & 1 \\
\hline 3 & Kadiri3 & 5 & 5 & 5 & 5 \\
\hline 4 & GJG 17 & 5 & 5 & 5 & 7 \\
\hline 5 & GJG 22 & 3 & 3 & 3 & 7 \\
\hline 6 & GG 20 & 3 & 3 & 1 & 7 \\
\hline 7 & JL 501 & 5 & 5 & 3 & 7 \\
\hline 8 & Somnath & 1 & 3 & 3 & 7 \\
\hline 9 & GG 5 & 3 & 7 & 5 & 9 \\
\hline 10 & GJG 9 & 5 & 5 & 5 & 5 \\
\hline 11 & GG 11 & 3 & 3 & 3 & 5 \\
\hline 12 & GJG 37A & 5 & 5 & 3 & 5 \\
\hline 13 & GAUG 10 & 5 & 5 & 5 & 7 \\
\hline 14 & BAU 13 & 5 & 5 & 5 & 5 \\
\hline 15 & GG 2 & 5 & 7 & 5 & 7 \\
\hline 16 & Kausal 16 & 5 & 5 & 3 & 5 \\
\hline 17 & GG 8 & 1 & 3 & 5 & 5 \\
\hline 18 & ICGV 91114 & 1 & 3 & 1 & 5 \\
\hline 19 & JL 775 & 1 & 1 & 3 & 5 \\
\hline 20 & Kadiri 6 & 3 & 5 & 5 & 7 \\
\hline 21 & Girnar 3(R) & 1 & 3 & 1 & 1 \\
\hline 22 & CS 186 & 5 & 5 & 5 & 9 \\
\hline 23 & IGS 2015-2 & 3 & 3 & 3 & 7 \\
\hline 24 & Jyoti (S) & 5 & 5 & 5 & 9 \\
\hline 25 & IGS 2015-1 & 3 & 5 & 5 & 5 \\
\hline \multicolumn{2}{|c|}{$\begin{array}{c}\text { Location Severity Index } \\
\text { (LSI) }\end{array}$} & 3.48 & 4.12 & 3.64 & 5.8 \\
\hline
\end{tabular}

Disease score $1=$ highly resistant $(0 \%), 1-3=$ resistant $(1-20 \%), 4-5=$ moderate resistance $(21-50 \%), 6-7=$ susceptible $(51-70 \%)$ and $8-9=$ highly susceptible $(71-100 \%)$. 


\section{Reactions of groundnut genotypes for late leaf spot}

Among the 25 genotypes four genotypes namely- GG 7, GG 20, ICGV 91114 and Girnar 3 showed 1 disease score which indicates highly resistant reactions against the leaf spot disease and nine genotypes TG 11, GJG 22, JL 501, Somnath, GG 11, GJG 37A, Kausal 16, JL 775 and IGS 2015-2 showed 3 disease score that indicates resistance disease reactions and 12 genotypes Kadiri 3, GJG 17, GG 5, GJG 9, GAUG 10, BAU 13, GG 2, GG 8, Kadiri 6, CS 186, Jyoti and IGS 2015-1 showed moderate resistance reaction and none of the genotypes showed susceptible and highly susceptible at the time of 75 day after showing.

Second screening was taken at 85 days after sowing in which among the 25 genotypes two genotype GG-11 and Girnar 3 showed 1 disease score that indicates highly resistance reactions against the disease and only one genotypes GG 7 showed 3 disease score indicating resistance reaction and 10 genotypes Kadiri 3, GJG 9, GG 11, GJG 37 A, BAU 13, Kausal 16, GG 8, ICGV 91114, JL 775 and IGS 2015-1 showed 5 disease score indicating moderate resistance, 9 genotypes GJG 17, GJG 22, GG 20, JL 501, Somnath, GAUG 10, GG 2, Kadiri 6 and IGS 2015-1 showed 7 disease score means susceptible reaction and three genotypes GG 5, CS 186 and Jyoti showed 9 disease score indicating highly susceptible reaction.

Two genotypes TG 11 and JL 775 showed highly resistance against early leaf spot nine genotypes showed resistance reaction and 12 genotypes showed moderate resistance and for late leaf spot two genotypes TG 11 and Girnar 3 showed highly resistance, one genotype showed resistance reaction and 10 genotypes showed moderate resistance that can be used for further resistance breeding programme. Similar results also reported by earlier researchers Mane (2004) and Hossain et al., (2007).

\section{References}

Anonymous. 2004. Food and Agricultural Organisation.

Bunting, A.H., Gibbons, R.W. and Wynne, J. C. 1985. Groundnut (Arachis hypogaea L.) pp: 747-800.

Hossain, M. D., Rahman, M. Z., Khatun, A. and Rahman, M. M. 2007. Screening of groundnut genotypes for leaf spot and rust resistance. International Journal of Sustainable Crop Production. 2(1): 0710.

ICRISAT. 2004. Regional Elite Groundnut Variety Trial 2004/05. ICRISATEastern and Southern Africa Groundnut Improvement Programme, Lilongwe, Malawi.

Levetin, E. and McMahon, K. 1999. Plants and Society. WCB/McGraw-Hill Madrid. 2: 477.

Mane, P. A. 2012. Screening of groundnut cultivars against tikka disease. Asian Journal of Biological.Science.7 (2): 189-191.

Pande, S., Bandyopadhyay, R., Blümmel, M., Rao, N. J., Thomas, D., and Navi, S. S. 2003. Disease management factors influencing yield and quality of sorghum and groundnut crop residues. Field Crops Research. 84(1-2): 89-103.

Tshilenge, L. L., Nkongolo, K. K. C., Kalonji, M.A., and Kizungu, R. V. 2012. Epidemiology of the Groundnut (Arachis hypogaea L.) Leaf Spot Disease: Genetic Analysis and Developmental Cycles. American Journal of Plant Sciences. 3: 582-588.

Upadhyaya, H. D., Reddy, L. J., Gowda, C. L. L., and Singh, S. 2006. Identification of diverse groundnut germplasm: Sources of early maturity in a core collection. 
Field Crops Research. 97(2-3): 261271.

Williams, W. 1959. The isolation of pure line from $\mathrm{f}_{1}$ hybrids in tomato and problems of heterosis in breeding species. Journal of Agricultural Sciences Cambridge. 53:
347-353.

Worthington, R. E., Hammons, R. O. 1971. Genotypic variation in fatty acid composition and stability of Arachis hypogaea L. Oleagineaux. 26:695-700.

\section{How to cite this article:}

Ishu Kumar Khute, S.S. Rao, Preeti Painkra, Naveen Markam, Krishna Tandekar and Nandan Mehta. 2018. Screening of Groundnut Genotypes for Early and Late Leaf Spot Disease. Int.J.Curr.Microbiol.App.Sci. 7(02): 2841-2845. doi: https://doi.org/10.20546/ijcmas.2018.702.346 